\title{
Obtaining and Preliminary Characterization of Some Polyethylene Composites with Nickel-Silver Ferrite Filler
}

\author{
ALINA RUXANDRA CARAMITU ${ }^{1}$, RADU DASCALU ${ }^{1 *}$, IOANA ION ${ }^{1}$, ANDREEA VOINA ${ }^{*}$, \\ IOSIF LINGVAY ${ }^{\mathbf{2}, 3}$ iD https://orcid.org/0000-0002-7152-304X \\ ${ }^{1}$ National Institute for Research and Development in Electrical Engineering INCDIE ICPE-CA, 313 Splaiul Unirii, Bucharest, \\ district 3, Romania \\ ${ }^{2}$ Research-Development Institute for Environmental Protection Technologies and Equipment - ICPE Bistrita SA, 7 Parcului, \\ Bistriţa, Romania \\ ${ }^{3}$ ELECTROVALCEA SRL, 19 Ferdinand, Râmnicu Valcea, Romania
}

\begin{abstract}
Samples of LDPE (low-density polyethylene) and LDPE-PANSA (low-density polyethylene 4-Amino-3-hydroxy- 1-naphthalenesulfonic acid) copolymer with AgO.5·NiO.5. $\mathrm{Fe}_{2} \mathrm{O}_{4}$ powder (as a filler) composites were developed. Following the preliminary characterizations on the thermooxidability (by thermal analysis techniques), the dielectric behavior (by dielectric spectroscopy technique), the mechanical behavior, etc. it was found that the developed materials do not show significant changes after $240 \mathrm{~h}$ exposure to $150 \mathrm{~mW} / \mathrm{m}^{2} \mathrm{UV}$. The addition of $3 w t \%$ PANSA in LDPE has the effect of increasing the mechanical performance of polymer composites with $\mathrm{AgO} .5 \cdot \mathrm{NiO} \cdot 5 \cdot \mathrm{Fe}_{2} \mathrm{O}_{4}$ filler. The addition of $15 \mathrm{wt} \%$ ferritic powder leads to significant increases in dielectric losses (by about $100 \%$ in the case of pure LDPE and about $185 \%$ of the LDPE copolymer with 3 wt\% PANSA) and to the increase of the real component of the relative permittivity (by about $34.4 \%$ in LPDE, respectively about $36.4 \%$ in LPDE copolymer / 3\% wt PANSA). Dielectric behavior of the investigated materials indicates that the effect of $\mathrm{AgO} 0.5 \cdot \mathrm{NiO} .5 \cdot \mathrm{Fe}_{2} \mathrm{O}_{4}$ powder in LDPE and of copolimer LDPE with 3 wt\% PANSA consists in the increasing of the shielding efficiency of electromagnetic waves - the maximum effect being recorded in the case of the composite material with the content: LDPE 84.5wt\%, $2.5 \mathrm{wt} \%$ / PANSA and $13 \% \mathrm{wt} \% \mathrm{AgO} .5 \cdot \mathrm{NiO} .5 \cdot \mathrm{Fe}_{2} \mathrm{O}_{4}$.
\end{abstract}

Keywords: composite, polyethylene, PANSA, ferrite, dielectric loss, permittivity, conductivity

\section{Introduction}

In the perspective of sustainable development, respectively the ensuring on long-term of the working and living conditions in a clean and healthy environment [1] of the mankind, the development of new materials for various applications is a priority issue. Due to the continuous increasing of the electricity production and consumers share which generate electromagnetic fields, the electromagnetic pollution of the environment in the built habitats is more and more pronounced [2] - with all the consequences on human health [3 - 6] and on the living matter [7 - 14].

The attenuation of the electromagnetic pollution level of the habitats is possible through electromagnetic screens made by suitable materials. Depending on the concrete conditions of using and synergistic demands of the environmental factors to which these materials are exposed, in addition to an acceptable attenuation of electromagnetic waves, they must simultaneously have a number of characteristics such as: mechanical performances (elasticity, resistance to breaking, etc.), resistance to UV radiation, resistance to the action of molds, etc. Mainly these performances can be ensured by composite materials based on polymers (which have adequate mechanical characteristics [15, 37], acceptable thermal stability [16-18, 38, 39], high resistance to the action of molds [10, 17, 19], UV resistance [20], reduced hydrophilicity [21] etc.) with filler that attenuates electromagnetic waves such as metal powders [22] or ferrite powders. Recent studies have shown that the elasticity and electrical conductivity of low-density polyethylene LDPE increases by the addition of 0.5 - 3wt\% PANSA - 4Amino-3-hydroxy-1-naphthalenesulfonic acid [23].

*email: radu.dascalu@icpe-ca.ro,andreea.voina@icpe-ca.ro 
On the other hand, increasing the lifetime of the polymeric materials exposed to various environmental factors such as chemical and microbiological aggression [24, 25], temperature [26-28], gamma radiation [28-31], UV [32] etc.) can be achieved by using natural antioxidants $[33,34,38]$ or synthetic antioxidants $[28,30]$.

Polymeric and composite materials based on polymers (especially those based on LDPE [40-46]) have a high resistance to the microorganisms action [40-48], which is why the pollution of the environment with plastic waste is increasingly pronounced [48-50]. Pro-oxidant additives [51] and fillers significantly increase the HDPE biodegradability.

In view of these considerations, the paper purpose is to prepare and preliminary characterize LPDEbased composites with and without the addition of PANSA with nickel-silver ferrite powder filler.

\section{Materials and methods}

By extrusion and injection technique, samples of polymeric material and polymer-based composite with nickel-silver ferritic powder filler have been obtained and preliminary characterized.

\subsection{Synthesis of nickel-silver ferritic powder}

The nickel-silver ferritic powder with $\mathrm{Ag} 0.5 \cdot \mathrm{Ni} 0.5 \cdot \mathrm{Fe}_{2} \mathrm{O}_{4}$ composition has been obtained by hot coprecipitation $\left(80^{\circ} \mathrm{C}\right)$ in strongly alkaline medium. Saturated solutions of $\mathrm{AgNO}_{3}, \mathrm{NiSO}_{4}$ and $\mathrm{Fe}_{2}\left(\mathrm{NO}_{3}\right)_{3}$ have been mixed with $\mathrm{Ag}^{+} / \mathrm{Ni}^{2+} / \mathrm{Fe}^{3+}$ molar ratio. The mixture has been heated to $80^{\circ} \mathrm{C}$ and with continuous stirring, the $5 \mathrm{M} \mathrm{NaOH}$ solution has been dosed until complete precipitation. After filtration the precipitate was calcined in an inert medium (nitrogen) at $400^{\circ} \mathrm{C}$. The obtained powder has been ground in a ceramic ball mill and sieved out with a 400 sieve.

All used reagents were of P.A. quality, manufactured by Merck.

\subsection{Obtaining of material samples}

For comparative evaluations of the chemical, dielectric and mechanical characteristics, samples of LDPE composite were prepared by extrusion with and without addition of $3 \mathrm{wt} \%$ PANSA, addition of $15 \mathrm{wt} \%$ nickel-silver ferritic powder filler.

The LPDE used pellets were of the BRALEN NA 7-25 type. PANSA powder was ACS reagent grade $\geq 90 \%$ manufactured by Merck.

The samples were performed in two stages. In the first stage, the components (LDPE, PANSA and nickel-silver ferritic powder) were mixed and the composite granules were obtained by extrusion (on a Brabender KETSE laboratory extruder). In the second stage the composite granules were injected (with an injection machine type dr Boy A35 - Germany) obtaining disk-shaped specimens with a diameter of $30 \mathrm{~mm}$ and a thickness of $2.5 \mathrm{~mm}$.

The working parameters on the extruder were:

- $\quad$ extruder screw speed $45 \mathrm{rpm}$;

- feed screw speed: $700 \mathrm{rpm}$;

- $\quad$ the temperatures on the heating areas of the extruder were shown in Table 1.

Table 1. Temperatures on the heating areas of the extruder

\begin{tabular}{|c|c|c|c|c|c|c|}
\hline Area & 1 & 2 & 3 & 4 & 5 & 6 \\
\hline Temperature $\left[{ }^{\circ} \mathrm{C}\right]$ & 145 & 150 & 155 & 160 & 165 & 170 \\
\hline
\end{tabular}

The working parameters on the injection machine were:

- closing force of the mold in the range: $302-317 \mathrm{kN}$;

- injection pressure: 550 bar;

- back pressure: 90 bar;

- injection mold temperature: $15-20^{\circ} \mathrm{C}$;

- the temperatures of the heating areas of the injection molding machine were shown in Table 2. 
Table 2. Temperatures on the heating areas of the injection molding machine

\begin{tabular}{|c|c|c|c|c|c|}
\hline Area & 1 & 2 & 3 & 4 & 5 \\
\hline Temperature $\left[{ }^{\circ} \mathrm{C}\right]$ & 165 & 160 & 155 & 150 & 145 \\
\hline
\end{tabular}

Thus, four samples of material with different compositions were prepared. The coding of the material samples and their composition are presented in Table 3.

Table 3. Prepared material samples and their coding

\begin{tabular}{|c|c|c|c|}
\hline \multirow{2}{*}{ Sample cod } & \multicolumn{3}{|c|}{ Content } \\
\cline { 2 - 4 } & LDPE [wt $\%]$ & PANSA [wt $\%]$ & $\operatorname{Ag} 0.5 \cdot \mathrm{Ni}_{0} 0.5 \cdot \mathrm{Fe}_{2} \mathrm{O}_{4}[\mathrm{wt} \%]$ \\
\hline M1 (reference) & 100 & 0 & 0 \\
\hline M2 & 97 & 3 & 0 \\
\hline M3 & 85 & 0 & 15 \\
\hline M4 & 84.5 & 2.5 & 13 \\
\hline
\end{tabular}

\subsection{Preliminary characterizations}

The obtained composite samples were preliminarily characterized by:

- determination of hydrophilicity (inflatability in water);

- resistance to UV radiation;

- mechanical characteristics;

- thermal analysis;

- dielectric characteristics.

The hydrophilicity determination has been done gravimetrically by initial weighing and after in water maintaining at $22 \pm 2^{\circ} \mathrm{C}$ for $240 \mathrm{~h}$ of five samples from each material sample and mediating the obtained mass variations. The weighings were performed on a digital analytical balance with an accuracy of \pm 0.0001g (type Precisa 320 XR -model XR125SM from Precisa Gravimetrics AG).

The effect of UV radiation was evaluated by comparing the results of mechanical, dielectric tests and thermal analysis before and after $240 \mathrm{~h}$ exposure to UV radiation at $40 \pm 5^{\circ} \mathrm{C}$ and $\mathrm{RH}=70 \pm 10 \%$. A Kolorlux Blacklight (UV) lamp Mercury HGW 160W / 27 230-240 V Hungary - $150 \mathrm{~mW} / \mathrm{m}^{2}$ [35] was used as a source of UV radiation.

The mechanical characterization was performed on a universal equipment, LFM 30kN model, Walter $\&$ Sai AG Switzerland Walter Bai, for determining the tensile strength in static regime of the materials. Thus, the tensile strength $R_{m}$, the tensile yield strength $R_{p}$, the elongation $A$ and the modulus of elasticity $E$ were determined.

Characterizations by coupled thermal analysis techniques (TG, DTG + DTA) were performed with a simultaneous TG/ DTG+DTA analyzer produced by Netzsch-Germany, in synthetic air atmosphere (gas - flow rate of $30 \mathrm{~cm}^{3} / \mathrm{min}$ ), at heating rate of $10 \mathrm{~K} / \mathrm{min}$. Measurements were made in the temperature range $20-650^{\circ} \mathrm{C}$. The mass of each sample was around $19 \mathrm{mg}$. The results of measurements were processed and graphically represented using the dedicated Proteus Software, from NetzschGermany.

The dielectric characteristics were determined by the dielectric spectroscopy technique. Determination of dielectric loss and conductivity vs. frequency - of the obtained composite samples was investigated at a temperature of $20 \pm 2^{\circ} \mathrm{C}$ by dielectric spectroscopy technique with 1296 Dielectric interface / AMTEK - Solartron Analytical.

\section{Results and discussions}

Thermal diagrams recorded on pure LDPE (reference - sample M1) before exposure for $240 \mathrm{~h}$ to UV radiation are shown in Figure 1.

The analysis of Figure 1 shows that at the progressive heating of the used LDPE, the material has an endothermic melting process at $\mathrm{T}_{\mathrm{m}}=119.9^{\circ} \mathrm{C}$, followed by a first exothermic oxidation process with the solid peroxides formation (without mass loss) at $\mathrm{T}_{1}=243.0^{\circ} \mathrm{C}$ and two major exothermic oxidation 
processes at $\mathrm{T}_{2}=394.1^{\circ} \mathrm{C}$ and $\mathrm{T}_{3}=531.9^{\circ} \mathrm{C}$ with gaseous products formation and results that the total mass loss $\Delta_{\mathrm{mt}}$ at $600{ }^{\circ} \mathrm{C}$ is $99.79 \%$.

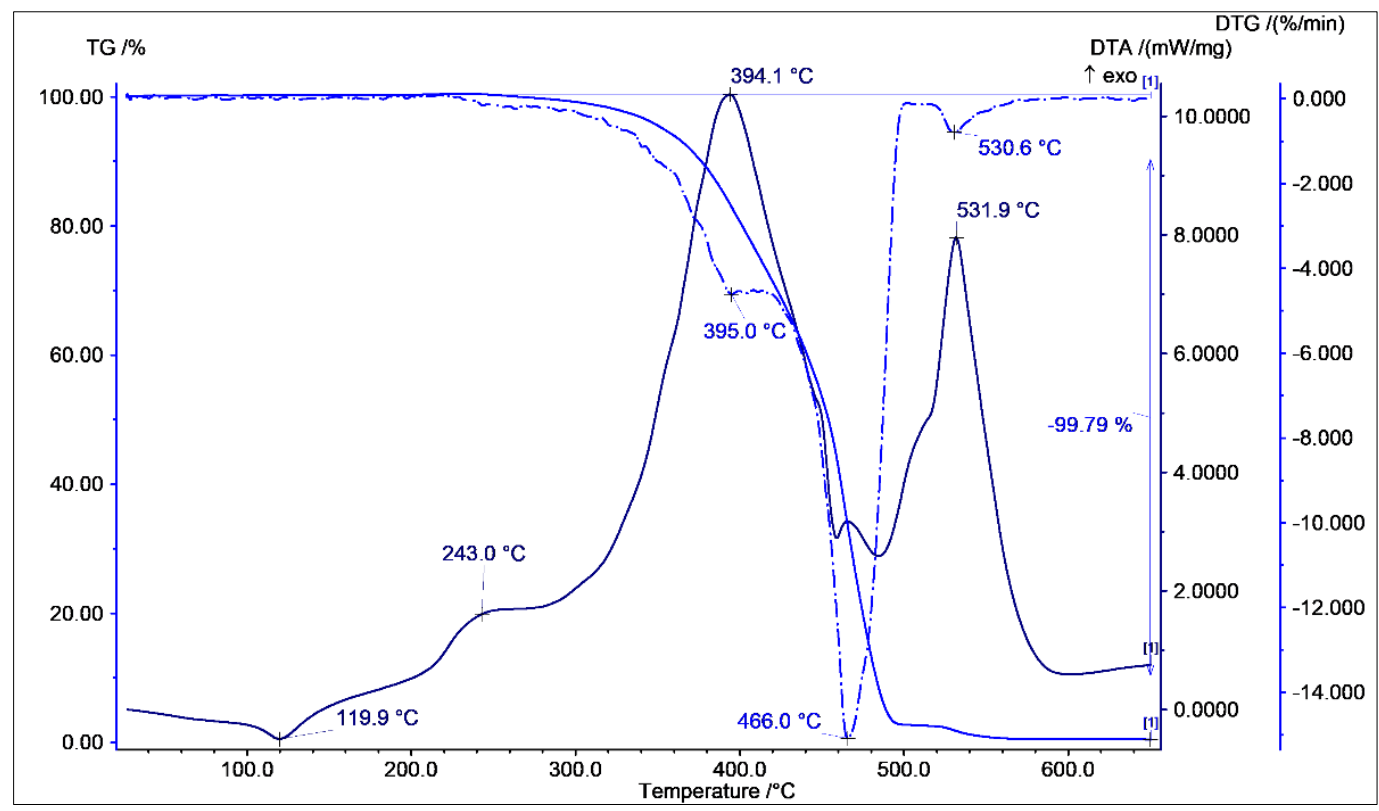

Figure 1. Thermal diagrams recorded on M1 (reference)

The thermal diagrams recorded on the LDPE sample with $15 \%$ ferritic powder $\mathrm{Ag} 0.5 \cdot \mathrm{Ni} 0.5 \cdot \mathrm{Fe}_{2} \mathrm{O}_{4}$ (M3 sample) before exposure to UV radiation are shown in Figure 2.

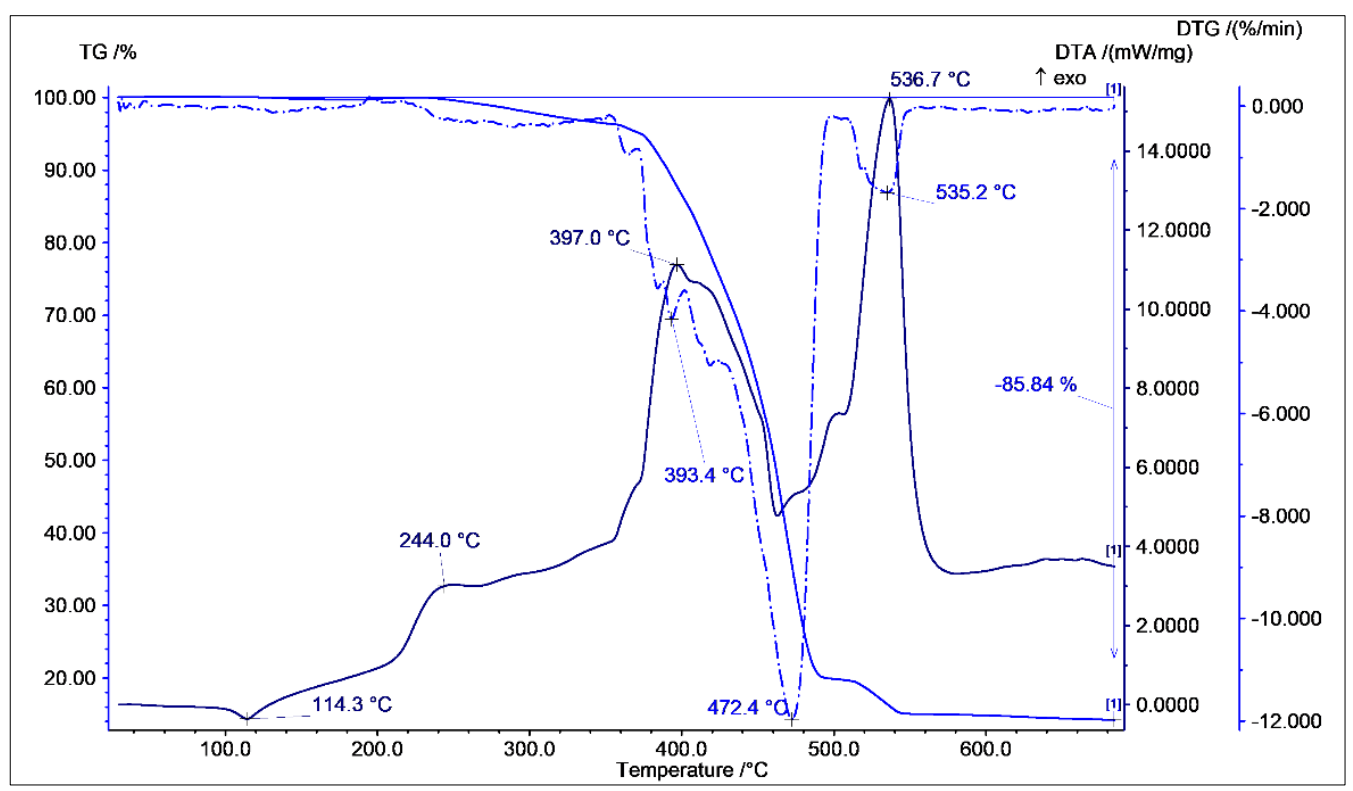

Figure 2. Thermal diagrams recorded on M3 (LDPE with $15 \%$ ferritic powder)

By comparative analysis of Figure 1 and Figure 2 it is found that by adding $15 \%$ ferritic powder in LDPE, the thermal behavior of the polymer has slight changes: $\mathrm{T}_{\mathrm{m}}$ decreases from $119.9^{\circ} \mathrm{C}$ to $114.3^{\circ} \mathrm{C}$ and slight shifts of the oxidation processes temperatures $\mathrm{T}_{1}, \mathrm{~T}_{2}$ and $\mathrm{T}_{3}$ take place. The addition of ferritic powder has the effect of $\Delta_{\mathrm{mt}}$ decreasing to $600^{\circ} \mathrm{C}$ with $15 \%$.

The thermal diagrams recorded on M1 and M3 samples after $240 \mathrm{~h}$ exposure to UV radiation are similar to those in Figure 1 and Figure 2 - slight changes registered being only at the values $T_{m}, T_{1}, T_{2}$ 
and $\mathrm{T}_{3}$. Table 4 comparatively shows the evolution of $\mathrm{T}_{\mathrm{m}}, \mathrm{T}_{1}, \mathrm{~T}_{2}, \mathrm{~T}_{3}$ and $\Delta_{\mathrm{mt}}$ values recorded on $\mathrm{M} 1$ and M3 samples before and after exposure for $240 \mathrm{~h}$ to UV radiation.

Table 4. Comparative evolution of $\mathrm{T}_{\mathrm{m}}, \mathrm{T}_{1}, \mathrm{~T}_{2}, \mathrm{~T}_{3}$ and $\Delta_{\mathrm{mt}}$ values recorded on $\mathrm{M} 1$ and $\mathrm{M} 3$ samples before and after exposure for $240 \mathrm{~h}$ to $\mathrm{UV}$ radiation of $150 \mathrm{~mW} / \mathrm{m}^{2}$

\begin{tabular}{|c|c|c|c|c|}
\hline \multirow{2}{*}{ Parameter } & \multicolumn{2}{|c|}{ M1sample } & \multicolumn{2}{c|}{ M3sample } \\
\cline { 2 - 5 } & Befor UV & After UV & Befor UV & After UV \\
\hline $\mathrm{T}_{\mathrm{m}}\left[{ }^{\circ} \mathrm{C}\right]$ & 119.9 & 118.0 & 114.3 & 117.5 \\
\hline $\mathrm{T}_{1}\left[{ }^{\circ} \mathrm{C}\right]$ & 243.0 & 252.0 & 244.0 & 233.0 \\
\hline $\mathrm{T}_{2}\left[{ }^{\circ} \mathrm{C}\right]$ & 394.1 & 404.9 & 397.0 & 401.8 \\
\hline $\mathrm{T}_{3}\left[{ }^{\circ} \mathrm{C}\right]$ & 531.9 & 527.9 & 536.7 & 542.1 \\
\hline$\Delta_{\mathrm{mt}} \& 600^{\circ} \mathrm{C}[\%]$ & -99.79 & -99.81 & -85.84 & 84.98 \\
\hline
\end{tabular}

The analysis of Table 4 shows that the effect of the UV exposure dose applied to M1 is to reduce the degree of cross-linking of the polymer $\left(\mathrm{T}_{\mathrm{m}}\right.$ decreases and $\mathrm{T}_{1}$ increases) unlike $\mathrm{M} 3$ where under the synergistic action of UV and ferritic powder, the cross-linking degree of the polymer increases $\left(\mathrm{T}_{\mathrm{m}}\right.$ increases and $\mathrm{T}_{1}$ decreases).

The thermal diagrams recorded on the LDPE sample with 3\% PANSA (M2 sample) before exposure to UV radiation are shown in Figure 3.

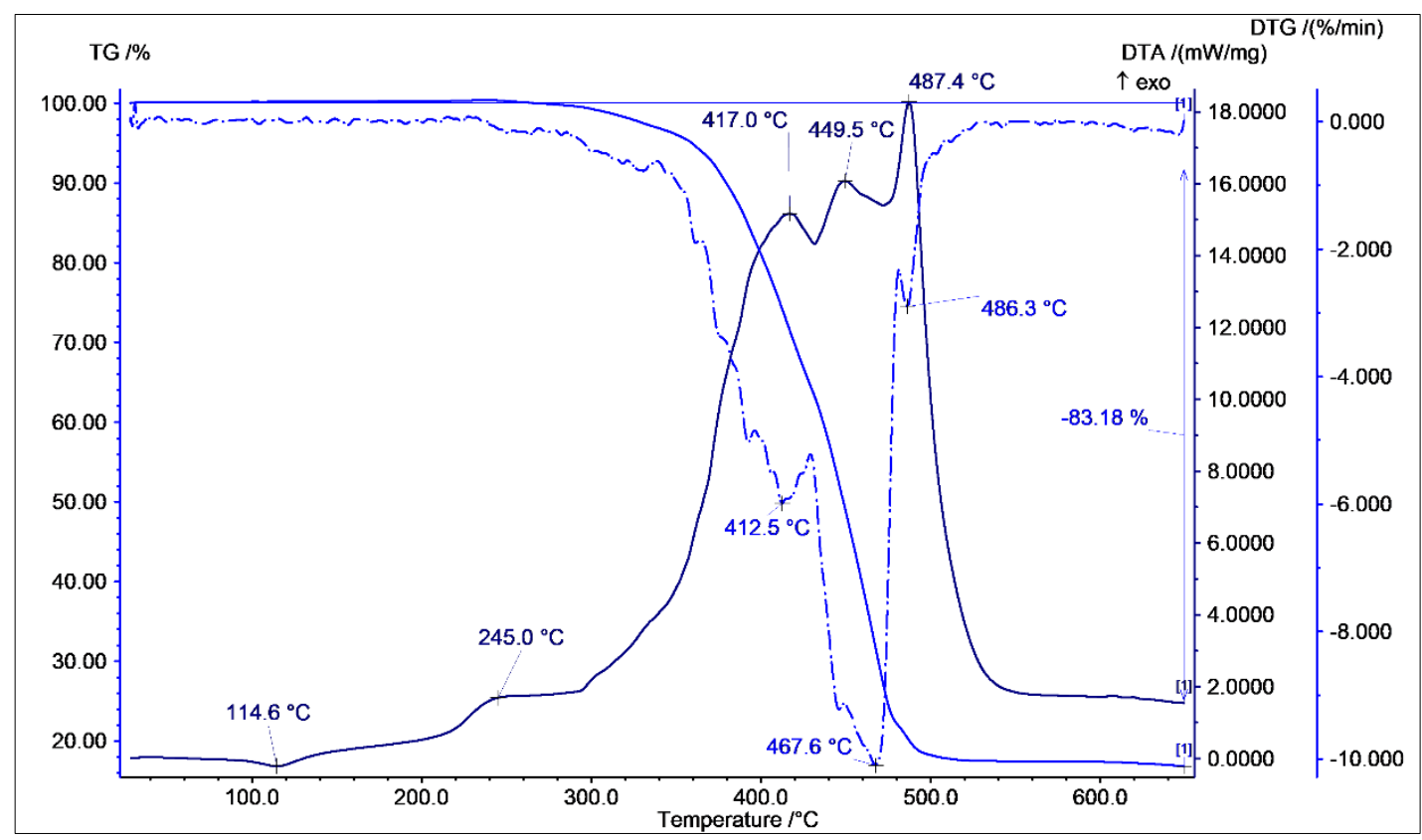

Figure 3. Thermal diagrams recorded on M2 (LDPE with 3wt\% PANSA)

By analyzing Figure 3 it is observed that at the progressive heating of LDPE with 3\% PANSA (M2) the material has an endothermic process of material melting at $\mathrm{T}_{\mathrm{m}}=114.6^{\circ} \mathrm{C}$, followed by a first exothermic oxidation process with formation of solid peroxides (without mass loss) at $\mathrm{T}_{1}=245.0^{\circ} \mathrm{C}$ and three major exothermic oxidation processes at $\mathrm{T}_{2}=417.0^{\circ} \mathrm{C}, \mathrm{T}_{3}=449.5^{\circ} \mathrm{C}$ and $\mathrm{T}_{4}=487.4$ with formation of gaseous products and thus results a total mass loss $\Delta_{\mathrm{mt}}$ of $-83.18 \%$ at $600{ }^{\circ} \mathrm{C}$.

By comparing Figure 3 with Figure 1 it is observed that the addition of $3 \%$ PANSA to LDPE, from the point of view of the thermal behavior has as effect a reduction of the melting temperature and the increasing of thermal stability $\left(\mathrm{T}_{1}, \mathrm{~T}_{2}\right.$ and $\mathrm{T}_{3}$ increase, a new oxidation stage appears with volatile products formation at $\mathrm{T}_{4}$ ). It is also found that at $\mathrm{M} 2$, the calcination residue at $650^{\circ} \mathrm{C}$ is approx. $17 \%$ compared with $\mathrm{M} 1$, where the degradation processes by oxidation are practically completed at $600^{\circ} \mathrm{C}$ (calcination residue is approx. $0.2 \%$ ). 
The thermal diagrams recorded on the LDPE sample $84.5 \mathrm{wt} \%$, PANSA $2.5 \mathrm{wt} \%$ and ferritic powder $13 \mathrm{wt} \%$ (sample M4) before exposure to UV radiation are shown in Figure 4.

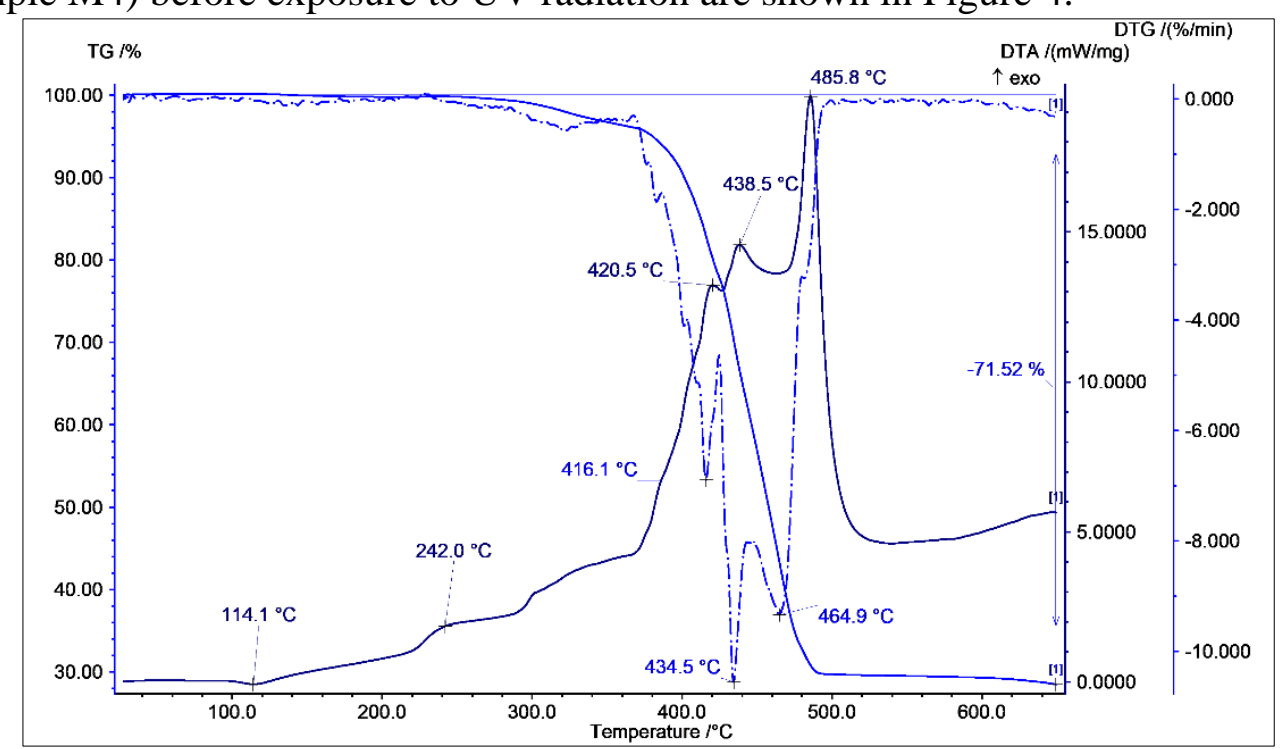

Figure 4. Thermal diagrams recorded on M4 (LDPE $84.5 \mathrm{wt} \%$, PANSA $2.5 \mathrm{wt} \%$ and ferritic powder $13 \mathrm{wt} \%$ )

By comparative analysis of Figure 3 and Figure 4 it is found that by adding ferritic powder in the LDPE + PANSA copolymer, the thermal behavior of the copolymer has slightly changes, more important being the $\mathrm{T}_{\mathrm{m}}$ decreasing with approx. $0.5^{\circ} \mathrm{C}$ and the temperature decreasing of the first thermooxidation process $\mathrm{T}_{1}$ with approx. $4^{\circ} \mathrm{C}$ (suggesting an increasing in the degree of cross-linking). The addition of ferritic powder has the effect of corresponding decreasing of $\Delta_{\mathrm{mt}}$ to $650^{\circ} \mathrm{C}$.

The thermal diagrams recorded on samples M2 and M4 after $240 \mathrm{~h}$ exposure to UV radiation are similar to those in Figure 3 and Figure 4 - slight changes registered only at the values $T_{m}, T_{1}, T_{2}$ and $T_{3}$. Table 5 comparatively shows the evolution of $\mathrm{T}_{\mathrm{m}}, \mathrm{T}_{1}, \mathrm{~T}_{2}, \mathrm{~T}_{3}$ and $\Delta_{\mathrm{mt}}$ values recorded on samples $\mathrm{M} 2$ and $\mathrm{M} 4$ before and after $240 \mathrm{~h}$ exposure to UV radiation.

Table 5. Comparative evolution of $\mathrm{T}_{\mathrm{m}}, \mathrm{T}_{1}, \mathrm{~T}_{2}, \mathrm{~T}_{3}$ and $\Delta_{\mathrm{mt}}$ values recorded on samples $\mathrm{M} 2$ and M4 before and after $240 \mathrm{~h}$ exposure to UV radiation of $150 \mathrm{~mW} / \mathrm{m}^{2}$.

\begin{tabular}{|c|c|c|c|c|}
\hline \multirow{2}{*}{ Parameter } & \multicolumn{2}{|c|}{ M2 sample } & \multicolumn{2}{c|}{ M4 sample } \\
\cline { 2 - 5 } & Before UV & After UV & Before UV & After UV \\
\hline $\mathrm{T}_{\mathrm{m}}\left[{ }^{\circ} \mathrm{C}\right]$ & 114.6 & 114.8 & 114.1 & 114.6 \\
\hline $\mathrm{T}_{1}\left[{ }^{\circ} \mathrm{C}\right]$ & 245.0 & 241 & 242.0 & 237.0 \\
\hline $\mathrm{T}_{2}\left[{ }^{\circ} \mathrm{C}\right]$ & 417.0 & 418.3 & 420.5 & 418.1 \\
\hline $\mathrm{T}_{3}\left[{ }^{\circ} \mathrm{C}\right]$ & 449.5 & 449.8 & 438.5 & 450.4 \\
\hline $\mathrm{T}_{4}\left[{ }^{\circ} \mathrm{C}\right]$ & 487.4 & 493.7 & 485.8 & 484.7 \\
\hline$\Delta_{\mathrm{mt}} \& 650^{\circ} \mathrm{C}[\%]$ & -83.18 & -83.21 & -71.52 & -70.20 \\
\hline
\end{tabular}

The analysis of Table 5 shows that the effect of the UV exposure dose applied to M2 and M4 is the increasing of the cross-linking degree of the copolymer ( $\mathrm{T}_{1}$ decreases).

The results of the determinations on the mechanical behavior of the material samples made before and after $240 \mathrm{~h}$ exposure at UV radiation are summarized in Table 6.

Table 6. Mechanical behavior of material samples made before and after $240 \mathrm{~h}$ exposure to UV radiation of $150 \mathrm{~mW} / \mathrm{m}^{2}$

\begin{tabular}{|c|c|c|c|c|c|c|c|c|}
\hline \multirow{2}{*}{ Sample } & \multicolumn{4}{|c|}{ Before UV } & \multicolumn{4}{c|}{ After UV } \\
\cline { 2 - 10 } & $\mathrm{R}_{\mathrm{m}}[\mathrm{MPa}]$ & $\mathrm{R}_{\mathrm{p}}[\mathrm{MPa}]$ & $\mathrm{A}[\%]$ & $\begin{array}{c}\text { E-Modules } \\
{[\mathrm{GPa}]}\end{array}$ & $\mathrm{R}_{\mathrm{m}}[\mathrm{MPa}]$ & $\mathrm{R}_{\mathrm{p}}[\mathrm{MPa}]$ & $\mathrm{A}[\%]$ & $\begin{array}{c}\text { E-Modules } \\
{[\mathrm{GPa}]}\end{array}$ \\
\hline M1 & 14.25 & 2.24 & 13.83 & 0.21 & 13.92 & 2.12 & 12.78 & 0.21 \\
\hline M2 & 14.81 & 2.87 & 15.71 & 0.31 & 14.98 & 4.15 & 16.43 & 0.30 \\
\hline
\end{tabular}




\begin{tabular}{|l|l|l|l|l|l|l|l|l|}
\hline M3 & 17.23 & 3.74 & 14.63 & 0.30 & 16.88 & 3.69 & 14.22 & 0.31 \\
\hline M4 & 15.05 & 2.98 & 17.51 & 0.51 & 15.68 & 4.25 & 17.78 & 0.39 \\
\hline
\end{tabular}

The analysis of Table 6 shows that the addition of PANSA to LDPE has the effect an increasing of the mechanical performances of the polymer - explainable by the significant increasing in the degree of cross-linking (Table 5). The decreasing in mechanical performance at M1 after UV exposure is due to decreasing in the crosslinking degree (highlighted by thermal analysis - Table 4). In the case of M3, although the cross-linking degree increases after UV exposure (Table 4), the mechanical performance decreases, which suggests that under the UV synergistic action and ferritic powder, the polymer chain breaks. It is important to note that - unlike M3 - in the case of LDPE-PANSA copolymer with ferritic powder filler (M4) under the UV action the breaking of the polymer chains does not occur.

The results of the determinations regarding the hydrophilicity of the elaborated materials, respectively the mass increases $\Delta_{\mathrm{m}}[\%]$ of the samples as a function of the exposure time / immersion in water, are comparatively presented in Figure 5.

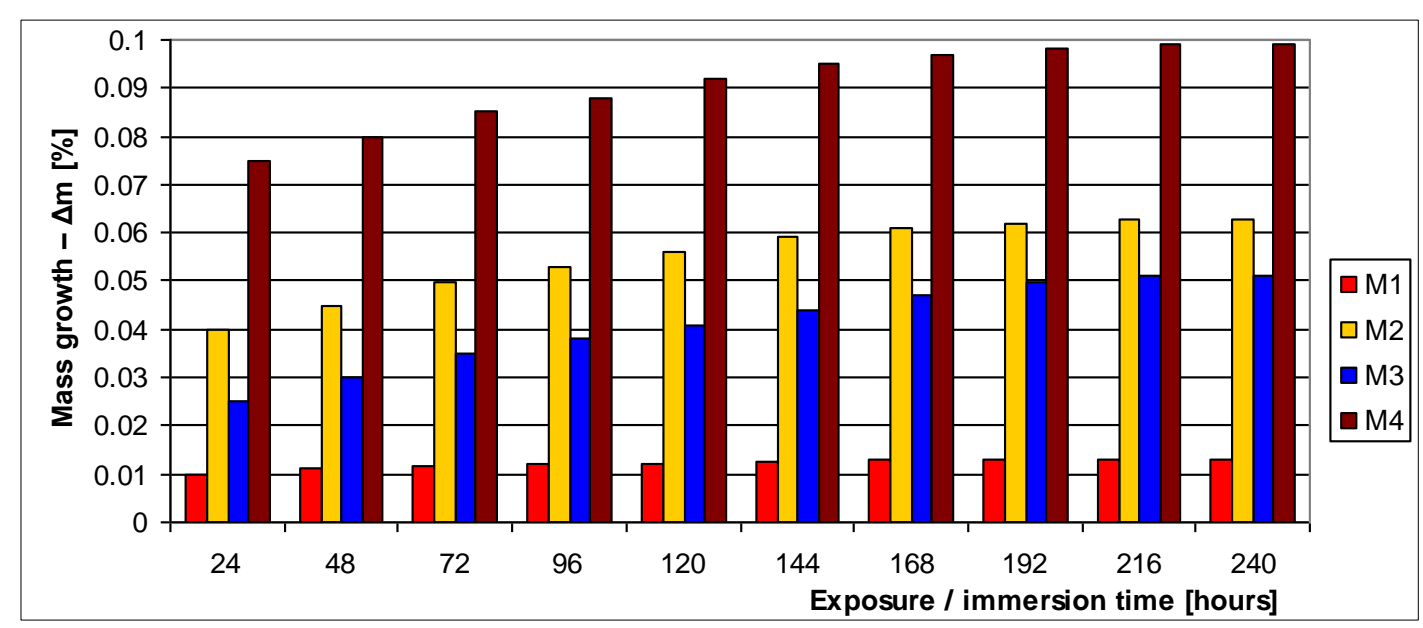

Figure 5. Evolution of mass growth during immersion of material samples in water

By analysis of Figure 5 it is observed that the water swelling of the M1 sample (reference - pure LDPE) is insignificant - up to $0.013 \%$ after $240 \mathrm{~h}$ of exposure). By adding $3 \mathrm{wt} \%$ PANSA in LDPE (sample M3) the swelling increasing is approx. 4 times - which is explained by the fact that PANSA has functional groups that form hydrogen bonds with water which hygroscopically absorbs. As a result of ferritic powder addition in M1 and M3 polymers, the swelling increasing is up to 5 times at M3 (0.05\% after $240 \mathrm{~h}$ of exposure) and only approx. 2 times at M4 $(0.99 \%$ at $240 \mathrm{~h}$ exposure). This behavior suggests that the addition of $3 \mathrm{wt} \%$ PANSA increases the fluidity of the formed copolymer which makes the copolymer film coating of ferrite particles more continuous and thus more difficult to absorb water. The values recorded for M3 and M4 are significantly lower than those reported (up to 20\%) for other polymeric composites [36]. It is noted that the increasing of water swelling at M2 and M4 may have the effect of resistance decreasing to the action of microorganisms (biodegradability increasing) [52].

The experimental results obtained by dielectric spectroscopy are presented in Figure 6 - dielectric losses $(\operatorname{tg} \delta)$, Figure 7 - the real component of the relative permittivity $\left(\varepsilon^{\prime}\right)$ and Figure 8 - electrical conductivity $(\sigma)$.

The analysis of Figure 6 revealed that in the range $500 \mathrm{~Hz}-1 \mathrm{MHz}$ the addition of $3 \%$ wt $\%$ PANSA in LDPE has as effect an insignificant increasing of approx. $16 \%$ of dielectric losses. The addition of 15 $\mathrm{wt} \%$ ferritic powder leads to significant increasing in dielectric losses - respectively of approx. $100 \%$ in the case of pure LDPE (M3 versus M1) and approx. 185\% of the LDPE + PANSA copolymer (M2 versus M4). 


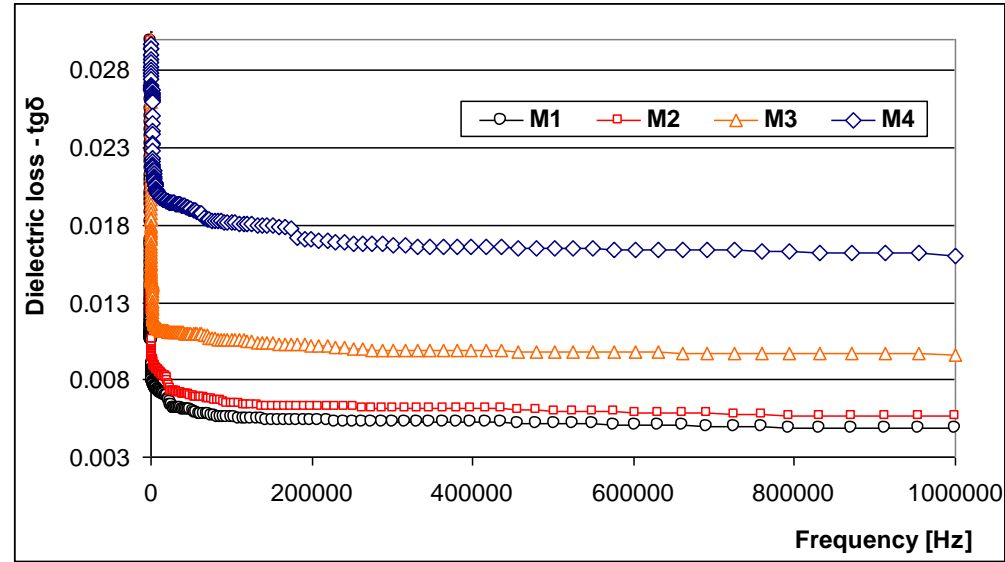

Figure 6. The evolution of $\operatorname{tg} \delta$ dielectric losses in the elaborated material samples

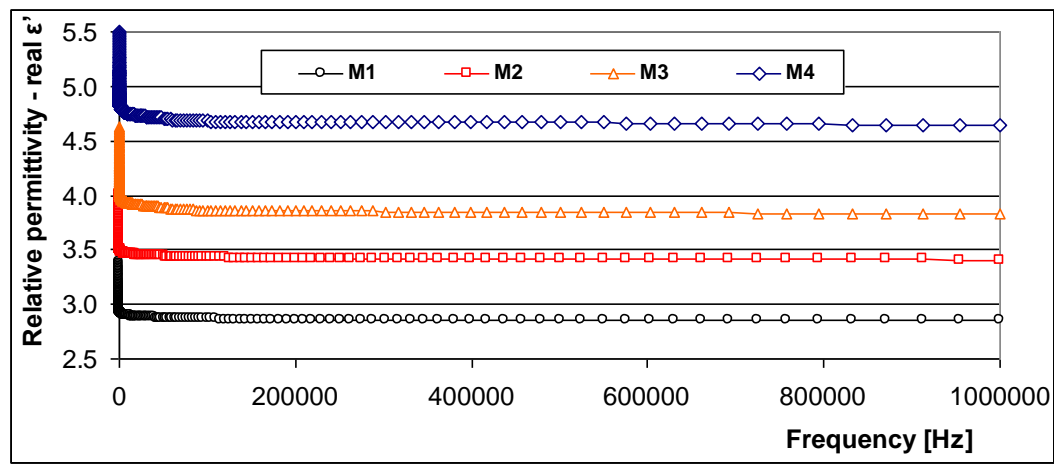

Figure 7. The evolution of the real component of the relative permittivity $\left(\varepsilon^{\prime}\right)$ of the elaborated material samples

By analyzing Figure 7 it is observed that in the range $500 \mathrm{~Hz}-1 \mathrm{MHz}$ the addition of $3 \%$ wt $\%$ PANSA in LDPE has as effect an increasing of approx. $19.5 \%$ of the real component of relative permittivity. The addition of $15 \%$ ferritic powder increases the relative permittivity by approx. $34.4 \%$ in LPDE (M3 versus M1), respectively with approx. 36.4\% in the LPDE / PANSA copolymer (M2 versus M4).

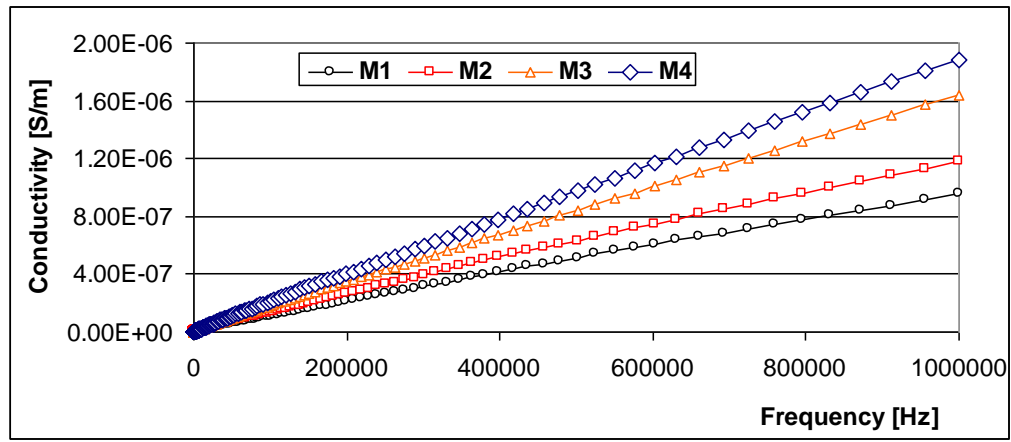

Figure 8. The evolution of the electrical conductivity of the elaborated material samples

Figure 8 shows that the electrical conductivity of the investigated materials, according to the analytical relations of the $\sigma$ functions (conductivity) $=\mathrm{F}$ (frequency) (1), (2), (3) and (4), increases approximately linearly with frequency increasing.

$$
\mathrm{y}_{\mathrm{M}}=1.9 \cdot 10^{-12} \mathrm{x}+4.7 \cdot 10^{-9}
$$




$$
\begin{aligned}
& \mathrm{y}_{M}=1.7 \cdot 10^{-12} \mathrm{x}+3.2 \cdot 10^{-9} \\
& \mathrm{y}_{\mathrm{M} 2}=1.2 \cdot 10^{-12} \mathrm{x}+4.4 \cdot 10^{-9} \\
& \mathrm{y}_{\mathrm{M} 1}=1.0 \cdot 10^{-12} \mathrm{x}+3.4 \cdot 10^{-9}
\end{aligned}
$$

It is noted that the increasing slope of conductivity is minimum at M1 $\left(1.0 \cdot 10^{-12}\right)$ and maximum in the case of M4 $\left(1.9 \cdot 10^{-12}\right)$ - the hierarchy of values being: M1 $<\mathrm{M} 2<\mathrm{M} 3<\mathrm{M} 4$.

This dielectric behavior of the investigated materials indicates that the effect of ferritic powder in LDPE polymer (M1) and copolymer (M2) consists in increasing of the shielding efficiency of electromagnetic waves - the maximum effect being recorded in the case of M4 composite.

\section{Conclusions}

Samples of LDPE and / or PANSA composite material with $\mathrm{Ag} 0.5 \cdot \mathrm{Ni} 0.5 \cdot \mathrm{Fe}_{2} \mathrm{O}_{4}$ powder filler were developed and preliminary characterized.

After experimental data analysis, it was found that:

-the incorporation of $\mathrm{Ag} 0.5 \cdot \mathrm{Ni} 0.5 \cdot \mathrm{Fe}_{2} \mathrm{O}_{4}$ in LDPE and in LDPE + $3 \mathrm{wt} \%$ PANSA does not significantly modify the melting point and the thermooxidability of the obtained composites;

-the addition of $3 \mathrm{wt} \%$ PANSA in LDPE has as effect the increasing of the mechanical performances of polymer composites with $\mathrm{Ag} 0.5 \cdot \mathrm{Ni} 0.5 \cdot \mathrm{Fe}_{2} \mathrm{O}_{4}$ filler;

-the addition of $3 \mathrm{wt} \%$ PANSA in LDPE has as effect the increasing of the molten polymer fluidity and a better coating of ferrite particles with polymer film;

-after $240 \mathrm{~h}$ exposure to $150 \mathrm{~mW} / \mathrm{m}^{2} \mathrm{UV}$, the thermal stability and respectively the thermooxidability of the elaborated materials does not change significantly - there was a slight tendency to increase the degree of the polymer cross-linking;

-the addition of $15 \mathrm{wt} \%$ ferritic powder leads to significant increasing of dielectric losses respectively of approx. 100\% in the case of pure LDPE (M3 versus M1) and approx. 185\% LDPE copolymer +3 wt $\%$ PANSA (M2 versus M4);

-the addition of $15 \%$ ferritic powder leads to the increase of the real component of the relative permittivity with approx. 34.4\% in LPDE (M3 versus M1) respectively with approx. 36.4\% in LPDE copolymer / 3\% wt PANSA (M2 versus M4).

Based on the above, it is concluded that in the case of HDPE-based polymeric composite, the addition of $15 \mathrm{wt} \%$ ferritic powder has the effect of increasing the shielding capacity of electromagnetic waves and the addition of $3 \mathrm{wt} \%$ PANSA has the effect of increasing both mechanical performance and water swelling.

Acknowledgments: The work was financially supported by Romanian Ministry of Research, Innovation and Digitization by project PN19310101-46N/2019 and by a project in collaboration with JIRN Dubna Rusia, position no. 12 from ordinal no. 397/27.05.2019.

\section{References}

1.E. A. STERE, I. POPA, Alarming Evolutions of Environment and Development for the Future of Mankind, Electrotehnica, Electronica, Automatica (EEA), vol. 65, no. 4, 2017, 193-203.

2.I. LINGVAY, A. VOINA, C. LINGVAY, C. MATEESCU, The impact of the electromagnetic pollution of the environment on the complex build-up media, Revue Roumaine des Sciences Techniques série Électrotechnique et Énergétique, Tome 53, No. 2bis, Avril-Juin, 2008, 95-112.

3.BOLTE, J.F.B., BALIATSAS, C., EIKELBOOM, T., VAN KAMP, I., Everyday exposure to power frequency magnetic fields and associations with non-specific physical symptoms, Environmental Pollution, Vol. 196, 2015, 224-229.

4.MASLANYJ, M.., SIMPSON, J., ROMAN, E., SCHÜZ, J., Power frequency magnetic fields and risk of childhood leukaemia: misclassification of exposure from the use of the 'distance from power line' exposure surrogate, Bioelectromagnetics, Vol. 30 (3), 2009, 183-188. 
5.BALIATSAS, C., VAN KAMP, I., KELFKENS, G., SCHIPPER, M., BOLTE, J., YZERMANS, J., LEBRET, E., Non-specific physical symptoms in relation to actual and perceived proximity to mobile phone base stations and powerlines, BMC Public Health, Vol. 11, 2011, Article number 421.

6.BALIATSAS, C., VAN KAMP, I., BOLTE, J., SCHIPPER, M., YZERMANS, J., LEBRET, E., Nonspecific physical symptoms and electromagnetic field exposure in the general population: Can we get more specific? A systematic review, Environment International, Vol. 41(1), 2012, 15-28.

7.SZEMERSZKY, R., ZELENA, D., BARNA, I., BÁRDOS, G., Stress-related endocrinological and psychopathological effects of short- and long-term $50 \mathrm{~Hz}$ electromagnetic field exposure in rats, Brain Research Bulletin, vol. 81 (1), 2010, 92-99.

8.RADU E., LIPCINSKI D., TĂNASE N., LINGVAY I., The influence of the $50 \mathrm{~Hz}$ electric field on the development and maturation of Aspergillus niger, Electrotehnica, Electronica, Automatizări (EEA), Vol. 63, (3), 2015, 68-74.

9.STANCU C., LINGVAY M., SZATMÁRI I., LINGVAY I., Influence of 50Hz Electromagnetic Field on the Yeast (Saccharomyces Cerevisiae) Metabolism, in: The 8th International Symposium on Advanced Topics in Electrical Engineering, Bucharest, Romania, May 23-25, 2013,

http://ieeexplore.ieee.org, DOI: 10.1109/ATEE.2013.6563449.

10.A. CARAMITU, N. BUTOI, T. RUS, A. M. LUCHIAN, S. MITREA, The Resistance to the Action of Molds of Some Painting Materials Aged by Thermal Cycling and Exposed to an Electrical Field of $50 \mathrm{~Hz}$, Mater. Plast., 54(2), 2017, 331-337.

11.LINGVAY, M., CARAMITU, AR., BORS, AM., LINGVAY, I, Dielectric spectroscopic evaluation in the extremely low frequency range of an aspergillus niger culture, STUDIA UBB CHEMIA, LXIV, 2, Tom I, 2019, 279-288, DOI:10.24193/subbchem.2019.2.23.

12.D. SANDU, I. LINGVAY, S. LÁNYI, D. D. MICU, C. L. POPESCU, J. BREM, L. C. BENCZE, C. PAISZ, The effect of electromagnetic fields on baker's yeast population dynamics, biocatalytic activity and selectivity, Studia Universitatis Babes-Bolyai, Chemia, LIV, 4, 2009, 195-201.

13.C. BARTHA, A. CARAMITU, M. JIPA, D. M. IGNAT, A. TÓKOS, Dielectric behavior of sludge from wastewater treatment, Studia UBB CHEMIA, LXV, 4, 2020, 85-93,

DOI:10.24193/subbchem.2020.4.07.

14.A. TÓKOS, C. BARTHA, M. JIPA, D. D. MICU, A. R. CARAMITU, I. LINGVAY, Interactions of Extremely Low-Frequency Electric Field with the Active Sludge Live Materia from Wastewater Treatments, 12th International Symposium on Advanced Topics in Electrical Engineering (ATEE), 2021, DOI: 10.1109/ATEE52255.2021.9425187.

15.A. BORS, D. LINGVAY, A. R. CARAMITU, I. IORDACHE, I. LINGVAY, Comparative Studies on the Electrical and Mechanical Behavior of Some Soldering and / or Impregnation Lacquers, Mater. Plast., 56(1), 2019. 129-132.

16.I. LINGVAY, C. STANCU, P. BUDRUGEAC, A. CUCOS, C. LINGVAY, Studies Concerning the Fast Ageing by Thermal Cycling of Power Cables, The $7^{\text {th }}$ International Symposium on Advanced Topics in Electrical Engineering, ATEE 2011, May 12-14, 2011, Bucharest, Romania, 437-440,

https://ieeexplore.ieee.org/document/5952210.

17.A. M. BORS, N. BUTOI, A. R. CARAMITU, V. MARINESCU, I. LINGVAY, The thermooxidation and resistance to molds action of some polyethylene sorts used at anticorrosive insulation of the underground pipelines, Mater. Plast, 54(3), 2017, 447-452.

18.T. RUS, A. M. BORS, A. R. CARAMITU, I. LINGVAY, D. I. VAIREANU, Comparative Studies on the Thermal Ageing of Some Painting materials, Mater. Plast., 55(2), 2018, 167-175.

19.T. RUS, E. RADU, I. LINGVAY, M. LINGVAY, O. C. CIOBOTEA-BARBU, C. CAMPUREANU, F. M. BENGA, G. C. LAZAR, D. I. VAIREANU, Resistance to the action of filamentous fungi upon some coatings materials, U.P.B. Sci. Bull., Series B, Vol. 79, Iss. 4, 2017, 167-180.

20.T. RUS, I. LINGVAY, A. R. CARAMITU, A. M. BORS, D. I. VAIREANU, Comparative Studies on the UV Radiations Resistance of Some Painting Materials, Mater. Plast., 54(4), 2017, 720-725. 
21.A. M. BORS, A. R. CARAMITU, D. MARIN, I. LINGVAY, The hydrophily of some lacquers for electrical use, Mater. Plast., 57(1), 2020, 122-132.

22.A. R. CARAMITU, S. MITREA, V. MARINESCU, G. A. URSAN, M. ARADOAIE, I. LINGVAY, Dielectric Behavior and Morphostructural Characteristics of Some HDPE Composites / Metal Nanopowders, Mater. Plast., 56(1), 2019, 103-109.

23.F. DOĞAN, K. ŞIRIN, F. KOLCU, I. KAYA, Conducting polymer composites based on LDPE doped with poly(aminonaphthol sulfonic acid), Journal of Electrostatics, Volume 94, August 2018, 85-93, https://doi.org/10.1016/j.elstat.2018.07.004.

24.LUNGULESCU, E.M., LINGVAY, I., UNGUREANU, L.C., RUS, T., BORS A.M. Thermooxidative behavior of some paint materials in natural ester based electroinsulating fluid, Mater. Plast., 55(2), 2018, 201-206.

25.BORS, A.M., LUNGULESCU, M.E., NICULA, N.O., CARAMITU, A.R., LINGVAY, I., Ageing of some lacquers due to microbiological stress, Mater. Plast., 56(2), 2019, 330-336,

https://doi.org/10.37358/MP.19.2.5181.

26.STANCU, C., NOTINGHER, P.V., NOTINGHER, P., LUNGULESCU, M., Space charge and electric field in thermally aged multilayer joints model, IEEE Trans. Dielectr. Electr. Insul., 23(2), 2016, 633-644, DOI: 10.1109/TDEI.2015.005363.

27.STANCU, C., HORAK, M., NOTINGHER, P.V., DUSEK, K., MACH, P., VESELY, P., SETNESCU, R., LUNGULESCU E.M., Thermal lifetime calculation of capacitor insulation using the activation energy method, IEEE Trans. Compon. Packag. Manuf. Technol., 10(10), 2020, 1647-1656, DOI: 10.1109/TCPMT.2020.3019275.

28.LUNGULESCU, M.E., ZAHARESCU, T., PODINA, C., Thermal and radiation stability of polyolefins modified with silica nanoparticles, J. Optoelectron. Adv. Mater., 16(5-6), 2014, 719-725.

29.LUNGULESCU, M., ZAHARESCU, T., JIPA, S., SETNESCU, R. SETNESCU, T., Chemiluminescence study on gamma-irradiated EPDM/IIR blends, J. Optoelectron. Adv. Mater., 10(4), 2008, 834-836.

30.ZAHARESCU, T., RAPA, M., LUNGULESCU E. M., BUTOI, N., Filler effect on the degradation of gamma-processed PLA/vinyl POSS hybrid, Radiat. Phys. Chem., 153, 2018, 188-197,

https://doi.org/10.1016/j.radphyschem.2018.09.025.

31.ZAHARESCU, T., KAYAN, L.I.P., LUNGULESCU, M.E., PARRA, D.F., LUGAO, A.B., EPDM recycling assisted by gamma-processing, Iran. Polym. J., 25(8), 2016, 725-730,

https://doi.org/10.1007/s13726-016-0460-6.

32.LUNGULESCU, E. M., LINGVAY, I., BORS, A. M., FORTUNA, L., NICULA N.O. Assessment of paint layers quality by FTIR and DSC techniques, Mater. Plast., 56(1), 2019, 87-91,

https://doi.org/10.37358/MP.19.1.5129.

3.JIPA, S., ZAHARESCU, T., KAPPEL, W., DUMITRESCU, C., MARIS, M., MANTSCH, A., LUNGULESCU M., Scavenger capacity of natural phenolics in some selected labiatae herbs, Optoelectron. Adv. Mat., 2(10), 2008, 669-673.

34.BANCUTA, O. R., CHILIAN, A., BANCUTA, I., ION, R. M., SETNESCU, R., SETNESCU, T., GHEBOIANU, A., LUNGULESCU M., FT-IR and UV-VIS characterization of grape extracts used as antioxidants in polymers, Rev. Roum. Chim., 60(5-6), 2015, 571-577.

35.***SR EN ISO 4892-3:2016 - Materiale plastice. Metode de expunere la surse luminoase de laborator. Partea 3: Lămpi fluorescente UV.

36.SUPRI A. G., IZZUDDEEN M., Tensile Properties, Swelling Behavior and Morphology Analysis of Recycled High Density Polyethylene / Natural Rubber / Chicken Feather Fibers (R-HDPE / NR / CFF) Composites: The Effects of Caprolactam, Advanced Materials Research, Vol. 844, 2013, 293-296, https://doi.org/10.4028/www.scientific.net/amr.844.293.

37.ILIE S., SETNESCU R., LUNGULESCU E. M., MARINESCU V., ILIE D., SETNESCU T., MARES G., Investigations of a mechanically failed cable insulation used in indoor conditions. Polymer Testing, Vol. 30(2), 2011, 173-182. 
38.JIPA S., ZAHARESCU T., KAPPEL W., SETNESCU T., LUNGULESCU M., OLTEANU R., Vegetal polyphenols as antioxidants in polymers. Journal of Optoelectronics and Advanced Materials, Vol. 10(4), 2008, 837-840.

39.SETNESCU R., LUNGULESCU M., BARA A., CARAMITU A., MITREA S., MARINESCU V., CULICOV O., Thermo-Oxidative Behavior of Carbon Black Composites for Self-Regulating Heaters. Advanced Engineering Forum, Vol. 34, 2019, 66-80.

40.JEON H.J., KIM M.N., Comparison of the functional characterization between alkane monooxygenases for low-molecular-weight polyethylene biodegradation, International Bio-deterioration and Biodegradation, Vol. 114, 2016, 202-208.

41.LAMPARELLI R.C.B.C., MONTAGNA L.S., BERNARDO DA SILVA A.P., MONTANHEIRO T.L.A., LEMES A.P., Study of the Biodegradation of PLA/PBAT Films after Biodegradation Tests in Soil and the Aqueous Medium, Biointerface Research in Applied Chemistry, Vol. 12 (1), 2022, 833 846.

42.MONTAZER Z., HABIBI NAJAFI M. B., LEVIND. B., Microbial degradation of low-density polyethylene and synthesis of polyhydroxyalkanoate polymers, Can J Microbiol., Vol. 65 (3), 2019, 224-234, DOI: 10.1139/cjm-2018-0335.

43.BONHOMME S., CUER, A., DELORT, A.-M., LEMAIRE, J., SANCELME, M., SCOTT, G., Environmental biodegradation of polyethylene, Polymer Degradation and Stability, Vol. 81 (3), 2003, 441-452, doi: 10.1016/S0141-3910(03)00129-0.

44.GAJENDIRAN, A., KRISHNAMOORTHY, S., ABRAHAM, J., Microbial degradation of lowdensity polyethylene (LDPE) by Aspergillus clavatus strain JASK1 isolated from landfill soil, 3 Biotech, Vol. 6 (1), art. no. 52, 2016, pp. 1-6.

45.ANBALAGAN S., VENKATAKRISHNAN H.R.R., RAVINDRAN J., SATHYAMOORTHY J., RANGABASHYAM K.A., RAGINI Y.P., SATHASIVAM J., SURESHBABU K., Hydrolytic Degradation of Polyethylene Terephthalate by Cutinase Enzyme Derived from Fungal BiomassMolecular Characterization, Biointerface Research in Applied Chemistry, Vol. 12 (10), 2022, 653 - 667. 46.EYHERAGUIBEL, B., TRAIKIA, M., FONTANELLA, S., SANCELME, M., BONHOMME, S., FROMAGEOT, D., LEMAIRE, J., LAURANSON G., LACOSTE J., DELORT, A.M., Characterization of oxidized oligomers from polyethylene films by mass spectrometry and NMR spectroscopy before and after biodegradation by a Rhodococcus rhodochrous strain, Chemosphere, Vol. 184, 2017, 366-374.

47.HARRISON J.P., BOARDMAN C., O'CALLAGHAN K., DELORT A.-M., SONG J., Biodegradability standards for carrier bags and plastic films in aquatic environments: A critical review, Royal Society Open Science, 5 (5), 2018 art. no. 171792. doi: 10.1098/rsos.171792.

48.GEYER R., JAMBECK J.R., LAW K.L., Production, use, and fate of all plastics ever made, Can J Microbiol, Vol. 65(3), 2019, 224-234.

49.ZHI L.X., Microplastics are Everywhere - but are they harmful?, Nature, Vol. 593(6), 2021, 22-25.

50.BIERMANN L, CLEWLEY D, MARTINEZ-VICENTE V, TOPOUZELIS K., Finding plastic patches in coastal waters using optical satellite data, Sci. Rep., Vol. 10(1), 2020, 1-10.

51.FONTANELLA, S., BONHOMME， S., KOUTNY， M., HUSAROVA， L., BRUSSON, J.M., COURDAVAULT, J.-P., PITTERI, S., SAMUEL G., PICHON G., LEMAIRE J., DELORT, A.M., Comparison of the biodegradability of various polyethylene films containing pro-oxidant additives, Polymer Degradation and Stability, Vol. 95 (6), 2010, 1011-1021.

52.DAS, M.P., KUMAR, S., Influence of cell surface hydrophobic in colonization and biofilm formation on LDPE biodegradation, International Journal of Pharmacy and Pharmaceutical Sciences, Vol. 5 (4), 2013, 690-694.

Manuscript receid: 4.06.2021 